\title{
Mutu Mikrobiologi Produk Surimi IkanTuna dan Produk Surimi di Pasar Swalayan
}

\author{
Joshua F.A. Wior*, Helen J. Lohoo, Engel V. Pandey, Netty Salindeho, \\ Josefa T. Kaparang, Daisy M. Makapedua, Verly Dotulong
}

\author{
Program Studi Teknologi Hasil Perikanan, Jurusan Pengolahan Hasil Perikanan, \\ Fakultas Perikanan dan Ilmu Kelautan, Universitas Sam Ratulangi, Manado. \\ *Korespondensi: joshuawior48@gmail.com
}

(Diterima 18-07-2020; Direvisi 05-08-2020; Dipublikasi 07-08-2020)

\begin{abstract}
Surimi is an export product and has a high economic value because it has high quality content, but surimi products can be contaminated. This study aims to determine the moisture content, $\mathrm{pH}$, Total Plate Count, and Salmonella from self-made surimi of tuna fish and surimi from retailed store. The value of self-made surimi is $820 \mathrm{cfu} / \mathrm{g}$ as from supermarkets is $120 \mathrm{cfu} / \mathrm{g}$ but it meets the Indonesian National Standard, which is max. $50,000 \mathrm{cfu} / \mathrm{g}$. The $\mathrm{pH}$ value for self-made surimi is 6.36 , and for surimi from retailed store is 7.36 . The moisture content of homemade surimi was $75.83 \%$ while surimi from retailed store was $70.33 \%$. Furthermore, there is no Salmonella detected of surimi both sample. It can be concluded that both samples can be consumed after proper cooking.
\end{abstract}

Keywords: $\quad$ surimi, Tuna fish, Moisture content, $p H$ value, detection of salmonella sp.

Surimi adalah produk ekspor dan memiliki nilai ekonomi tinggi karena memiliki konten berkualitas tinggi, tetapi produk surimi dapat terkontaminasi. Penelitian ini bertujuan untuk menentukan kadar air, pH, Angka Lempeng Total, dan Salmonella dari surimi buatan ikan tuna dan surimi yang diambil dari supermarket. Hasil penelitian menunjukkan bahwa rendemen ikan surimi Tuna adalah $(63,50 \%)$. Nilai surimi buatan sendiri adalah $820 \mathrm{cfu} / \mathrm{g}$ karena dari supermarket adalah $120 \mathrm{cfu} / \mathrm{g}$ tetapi memenuhi Standar Nasional Indonesia, yaitu Max. $50.000 \mathrm{cfu} / \mathrm{g}$. Nilai pH untuk surimi buatan sendiri adalah 6.36, dan untuk surimi yang diambil dari supermarket adalah 7.36. Juga, ini menunjukkan bahwa $\mathrm{pH}$ surimi buatan rumah bersifat asam sementara surimi dari supermarket basah. Nilai rata-rata untuk kadar air surimi buatan sendiri adalah $75,83 \%$ dengan surimi diambil dari supermarket yaitu 70,33\% karena surimi diambil dari supermarket, memiliki kadar air lebih rendah dari surimi buatan sendiri. Produk dapat dikonsumsi dengan aman setelah proses pemasakan yang benar.

Kata kunci: surimi, ikan Tuna, kadar air, nilai $p H$, deteksi Salmonella sp.

\section{PENDAHULUAN}

Sektor perikanan Indonesia pada era globalisasi ini memiliki prospek pengembangan yang sangat potensial. Hal ini dapat dilihat dari industri pangan hasil perikanan yang semakin berkembang dan beragam jenisnya. Salah satu bahan pangan perikanan yang pada saat ini sedang berkembang di Indonesia adalah surimi.

Ikan tuna merupakan komoditas ekspor utama bagi Indonesia. Lokasi penyebarannya di Indonesia terletak di laut Barat Sumatera, Selatan Jawa, Selat Malaka, Timur Sumatera, Utara Jawa, Bali-Nusa Tenggara Timur, Kalimantan, Selatan Sulawesi, Utara Sulawesi dan MalukuPapua. Nilai produksi tuna yang terus mengalami peningkatan dari tahun 2004 sebesar 112.796 ton (KKP 2015a) hingga tahun 2015 menjadi 167.800 ton (KKP 2015b).

Untuk lebih meningkatkan ketertarikan masyarakat, terhadap konsumsi hasil olahan ikan maka perlu terus dilakukan diversifikasi olahan ikan dengan menghadirkan produk-produk yang lebih inovatif sehingga mampu meningkatkan selera konsumsi terhad ap produk olahan ikan. Salah satu yakni dilakukan usaha restrukturisasi daging. Salah satu aplikasi restrukturisasi daging ikan adalah proses pembuatan surimi.

Ikan memiliki nilai nutrisi yang tinggi, namun ikan merupakan bahan pangan yang mudah rusak. Salah satu penyebabnya adalah kontaminasi mikroba dan kerusakan yang diakibatkannya sakalipun produk disimpan pada suhu rendah. Penyimpanan ikan di dalam freezer dalam rangka memperpanjang umur simpan dapat menurunkan kualitas dari produk daging ikan (Okazaki dan Kimura, 2013). Hal tersebut akan menurunkan kualitas sensori ikan terutama tekstur selama 
periode penyimpanan. Berdasarkan latar belakang di atas maka penulis merujuk pada metodologi penelitian ini.

Surimi adalah produk ekspor dan memiliki nilai ekonomis yang tinggikarena memiliki kandungan mutu yang baik, tetapi produk surimi bisa terkontaminasi jika suhunya tidak dijaga, yang salah satunya bakteri salmonella. Oleh karena itu penelitian dilakukan untuk mengetahui jumlah total bakteri danmengidentifikasi bakteri salmonella pada produk surimi.

\section{MATERIAL DAN METODE}

\section{Alat dan Bahan}

Alat-alat yang digunakan dalam untuk pembuatan surimi ini adalah peralatan pisau, telenan, alat pemeras surimi, kain kafan, blender, keranjang, plastik, alat yang digunakan untuk pengujian surimi adalah inkubator (NDO-410), autoclave (HICLAVE), cawan petri, cawan porselen, gelas ukur, gelas beker, mikro pipet, spatula, erlenmeyer, tabung hach, jarum ose, Bunsen, timbangan analitik (OHAUS), hotplate, stirrer, pH meter (ORION).

Bahan-bahan yang digunakan untuk pembuatan surimi adalah surimi ikan tuna dari pasar swalayan dan surimi olahan sendiri, garam, gula, es batu, air RO, kulkas (Samsung), tissue, bahan yang digunakan untuk pengujian surimi adalah $\mathrm{NaCl} 0,9 \%$, aluminum foil, akuades, Nutrient Agar (Merck), Salmonella Shigella Agar (SSA) (liofilchem S.r.l.), larutan penyangga (buffer).

\section{Pembuatan Surimi Buatan Sendiri}

Pengambilan sampel ikan tuna dari tempat frozen tuna yang dari Tomohon sebanyak $1 \mathrm{~kg}$ yang sudah menjadi steak, kemudian ikan-ikan tersebut diisi dalam cool box, perbandingan ikan dengan es adalah 1:2, Ikan yang ada di cool box dikeluarkan satu persatu untuk dilelehkan, kemudian daging ikan dicuci bersih, pencucian bertujuan untuk menghilangkan darah yang ada pada daging ikan. Daging ikan yang sudah dicuci kemudian dipotong kecil-kecil, pemotongan ini bertujuan untuk mempermudah pada saat proses penggilingan, kemudian daging ikan dihaluskan dengan menggunakan blender sehingga didapat daging lumat halus menyerupai bentuk surimi, pencucian 2 (leaching), Dalam penelitian ini dilakukan analisis mikrobiologi pada surimi meliputi Uji ALT, surimi yang telah diproses kemudian dikemas dalam kemasan plastik dan dibekukan dalam freezer selama 1 malam, dalam penelitian dilakukan analisis bakteri salmonella pada ikan yang dibuat dari surimi dan dilanjutkan analisis kimia meliputi rendemen, uji pH dan uji kadar air.

\section{Surimi pasar swalayan}

Pengambilan sampel surimi dari tempat Transmart Bahu Mall sebanyak 1 bungkusan disampel, dalam penelitian ini dilakukan analisis mikrobiologi pada surimi meliputi Uji ALT, selanjutnya dilakukan analisis bakteri salmonella pada 2 merk sampel surimi dan dilanjutkan analisis kimia meliputi uji $\mathrm{pH}$ dan uji kadar air.

\section{Parameter Uji}

Adapun parameter yang diujikan pada penelitian ini adalah analisa $\mathrm{pH}$ dan kadar air (AOAC, 2005), analisis Angka Lempeng Total (SNI 2332.3-2015), dan deteksi Salmonella dengan media Salmonella Shigella Agar.

\section{HASIL DAN PEMBAHASAN}

\section{Angka Lempeng Total (ALT)}

Kandungan mikroorganisme merupakan salah satu faktor penentu kualitas surimi. Parameter ini menentukan tingkat kemunduran mutu dari daging ikan. Hasil perhitungan koloni bakteri pada surimi buatan sendiri dan surimi yang diambil dari pasar swalayan dapat dilihat pada Gambar 1.

Gambar 1. Menunjukan bahwa jumlah koloni bakteri yang tumbuh pada surimi surimi buatan sendiri adalah $820 \mathrm{cfu} / \mathrm{g}$ dan untuk surimi dari pasar swalayan adalah $120 \mathrm{cfu} / \mathrm{g}$. Tetapi masih memenuhi (SNI 01-2332.3-2006) yaitu Maks. $50.000 \mathrm{cfu} / \mathrm{g}$. Berdasarkan data di atas bahwa untuk nilai koloni bakteri tertinggi yaitu pada sampel surimi dari pasar swalayan, karena sampel surimi dari pasar swalayan sudah melewati masa penyimpanan sehingga surimi dari pasar swalayan mengalami peningkatan jumlah mikroba. Hal ini sejalan dengan Santoso et al. (2011), surimi ikan 
pari dan kembung yang disimpan pada refrigerator selama 6 dan 9 hari mengalami peningkatan jumlah mikroba.

\section{Pemeriksaan Kontaminasi Salmonella sp}

Hasil pemeriksaan cemaran Salmonella sp pada sampel surimi yang dibuat sendiri dan sampel surimi yang diambil dari pasar swalayan pada media SSA dapat dilihat pada Tabel 1.

Tabel 1. Hasil pemeriksaan bakteri Salmonella sp media SS-Agar, pada sampel surimi buatan sendiri dan surimi dari pasar swalayan

\begin{tabular}{cc}
\hline Perlakuan & Indentifikasi Salmonella \\
\hline S A & - \\
S B & -
\end{tabular}

Ket.: SA (Surimi buatan sendiri); SB (Surimi dari pasar swalayan).

Tabel 1 menunjukan, bahwa sampel SA dan sampel SB negatif Salmonella sp. Menurut Muktiningsih et al. (2016), SSA adalah media selektif untuk mengisolasi bakteri anggota genus salmonella dan bakteri anggota genus shigella, tetapi media SSA tidak disarankan untuk pengujian bakteri anggota genus shigella karena beberapa strain shigella akan terhambat. Pemeriksaan pada media SS-Agar digunakan pada saat pengayaan, namun demikian berdasarkan kriteria koloni yang tumbuh pada media ini, pernyataan Zaraswati (2006), bahwa hasil uji SSA memberikan zona kuning di antara koloni hitam dan pertumbuhan mikrobanya berwarna merah atau hitam dan sampel SA dan SB menunjukkan tidak ada koloni berwarna.

\section{Hasil Analisa pH}

Hasil antara surimi yang dibuat sendiri dan surimi yang diambil dari pasar swalayan terhadap nilai pH surimi keduanya dapat dilihat pada Gambar 2.

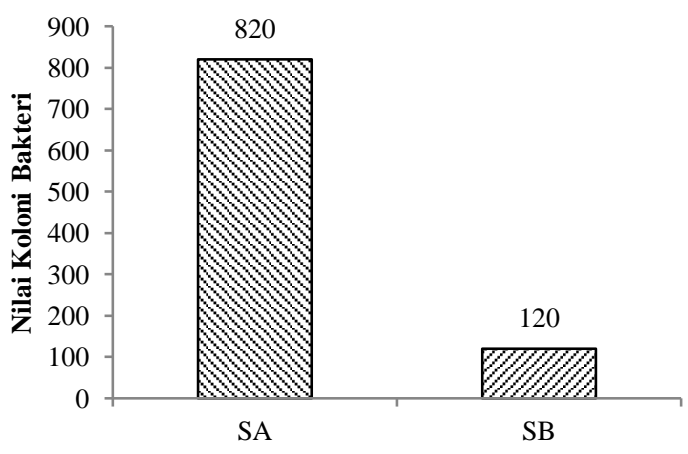

Gambar 1. Nilai Koloni Bakteri surimi buatan sendiri dan surimi dari pasar swalayan.

Ket.: SA (surimi buatan sendiri); SB (surimi dari pasar swalayan).

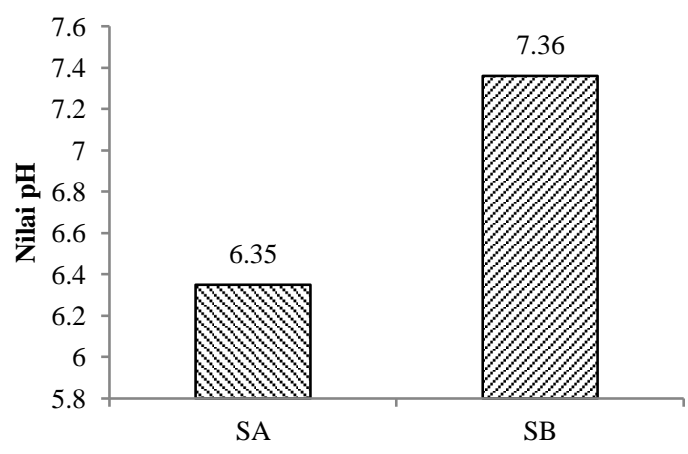

Gambar 2. Nilai pH surimi buatan sendiri dan surimi dari pasar swalayan.

Gambar 2. Menunjukan bahwa nilai pH (SA) surimi buatan sendiri adalah 6,36, dan untuk surimi (SB) yang diambil dari pasar swalayan adalah 7,36. Dari hasil penelitian ini dapat dilihat bahwa nilai $\mathrm{pH}$ surimi buatan sendiri bersifat asam sedangkan surimi dari pasar swalayan bersifat basah. Menurut Park (2005), menyatakan bahwa kondisi pH surimi 6-7 merupakan kondisi normal untuk menghasilkan nilai kekuatan gel yang baik. Bila $\mathrm{pH}>8$ nilai kekuatan gel cenderung lemah dan tidak homogen, begitu pula bila $\mathrm{pH}<6$ protein myofibril tidak stabil karena terjadi pelepasan enzim ATPase sehinggah menurunkan nilai kekuatan gel. Sarie et al. (2018), menyatakan tinggi rendahnya nilai gel surimi yang diperoleh pada penelitian diduga karena kandungan protein yang terdapat pada jenis ikan yangdigunakan berbeda-beda.

\section{Hasil Analisa Kadar Air}

Hasil analisa kadar air pada surimi buatan sendiri dan surimi yang diambil dari pasar swalayan dapat dilihat pada Gambar 3 di bawah ini. 


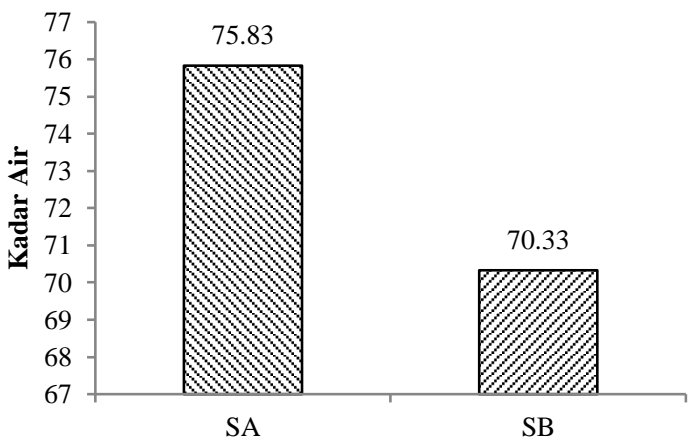

Gambar 3. Analisa Kadar Air surimi buatan sendiri dan surimi dari pasar.

Ket.: A (surimi buatan sendiri); B (surimi dari pasar swalayan).

Gambar 3 menunjukan bahwa nilai rata-rata untuk kadar air surimi buatan sendiri yaitu $75,83 \%$ dengan surimi yang diambil dari pasar swalayan yaitu $70,33 \%$. Hal ini menunjukan bahwa surimi yang diambil dari pasar swalayan kadar airnya lebih rendah dibanding surimi yang dibuat sendiri karena surimi buatan sendiri tanpa penambahan bahan pengikat sedangkan surimi dari pasar swalayan sudah ditambahkan bahan pengikat, dan hal ini sama dengan penelitian Wicaksana et al. (2014), surimi tanpa bahan pengikat (kontrol) memiliki kandungan air paling tinggi sebesar $78,34 \%$ diduga pada surimi kontrol terdapat air bebas, dan air terikat, sedangkan pada surimi dengan penambahan bahan pengikat hanya terdapat air pengikat saja. Menurut Winarno (2002), jumlah kadar air pada produk dipengaruhi oleh kadar protein oleh bahan baku yang digunakan. Daya ikat air semakin kuat apabila jumlah protein myofibril (aktin dan myosin) juga semakin besar.

\section{KESIMPULAN}

Perbedaan jenis ikan dan perbedaan pembuatan surimi dapat memberikan pengaruh yang berbeda dari kedua pengujian tersebut. Hasil penelitian menunjukkan bahwa kadar air surimi yang dibeli dari supermarket lebih rendah dibandingkan surimi yang dibuat sendiri sedangkan nilai $\mathrm{pH}$ surimi yang dibeli dari supermarket lebih tinggi dari surimi yang dibuat sendiri. Tidak terdeteksi Salmonella sp. Pada kedua sampel yang diujikan.

\section{DAFTAR PUSTAKA}

Association of Official Analytical and Chemists (AOAC). 2005. Official Methods of Analysis. Association of Official Analytical Chemists 18th ed. Chemist Inc.

[BSN] Badan Standardisasi Nasional. 2006. Surimi Beku-Bagian 1: Spesifikasi. SNI 01-2694.1-2006. Badan Standardisasi Nasional (BSN).

[KKP] Kementerian Kelautan dan Perikanan 2015a. 2015. Statistik Perikanan Tangkap Menurut Provinsi. Kementerian Kelautan dan Perikanan.

Muktiningsih, F, Kurniadewi\& Immanuel, ORP. 2016. Isolasi Amflikasi dan Sekuensing Fragmen 1,9 Kilobasa Gen HeatShock Protein 70 Salmonella entericaSerovarThypi. Jurnal Kimia dan Pendidikan Kimia, vol. 11, no. 1, hal. $32-40$.

Okazaki E, d. K. 2013. Frozen surimi and surimi-based products. In: Boziaris I, editor. Seafood processing: technology, quality and safety. Hoboken, NJ: John Wiley\& Sons., hal. 209-234.

Park, J. W. 2005. Surimi and Surimi Seafood. CRS Press, Taylor \& Francis Group., 961 hlm.

Santoso, J., Ling. F., Handayani, R. 2011. Pengaruh Pengkomposisian dan Penyimpanan Dingin Terhadap Perubahan Karakteristik Surimi Ikan Pari (Trygon sp.) Dan Ikan Kembung (Rastrelliger sp.). Jurnal Teknologi Pangan, :1-15.

Sarie.O.T., Asikin.A.N., Kusumaningrum.I. 2018. Pengaruh perbedaan jenis ikan terhadap karakteristik gel surimi. Ziraa'ah. , Vol. 43 No. 3 :266-272.

Wicaksana.F.C., Agustini.T.W., Rianingsih.L. 2014. Pengaruh Penambahan Bahan PengikatTerhadap Karakteristik Fisik Surimi Ikan Patin (Pangasius hypophthalmus). Jurnal Pengolahan dan Bioteknologi Hasil Perikanan, Vol. 3 No. 3: 1-8.

Winarno, F. G. 2002. Kimia Pangan dan Gizi. Jakarta: PT Gramedia Pustaka Utama.

Zaraswati, D. 2006. Mikrobiologi Farmasi. Makassar. Universitas Hasanuddin. 